Some observations on the radiocarbon and cosmogenic isotope dating of petroglyphs, Foz Coa,

Watchman, Alan

Antiquity; Mar 1998; 72, 275; ProQuest Central

pg. 197

NOTES

197

fen, Antiquity 66: 948-55.

HEALY, F. 1996. The Wissey Embayment: evidence for pre-Iron Age occupation accumulated prior to the Fenland Survey, East Anglian Archaeology 78

HedGes, R.E.M. R.A. HOLSLEY, C. BRONK RAMSEY \& G.J. VAN KLINKEN. 1994. Radiocarbon dates from the Oxford AMS systems Archacometry Datelist 18. Archaeometry 36: 33774.

HUCHES. T. MCKENNY. 1916. Notes on the Fenland with a description of the Shippea Hill Man. Cambridge: Cambridge University Press.

LEAF. C.S. $193 \overline{5}$. Report on the excavation of two sites in Mildenhall Fen. Proceedings of the Cumbridge Antiquarion Society $35: 106-28$.

MARTIN, E.A. 1988. Swales Fen. Suffolk: a Bronze Age cooking pit?, Antiquitv 62: 358-59.

MARTIN, E.A. \& P, MuRPhy. 1988. West Row Fen, Suffolk: a
Bronze Age fen-edge settlement site. Antiquity 62: 3528.

MuRpHY, P. 1984. Environmental archacology in East Anglia, in H.C.M. Keeley (ed.). Environmental archaeology: a regional review: $13-42$. London: DOE. Directorate of Ancient Monuments and Historic Buildings occasional paper 6.

PETERSEN . F. 1972. Traditions of multiple burial in later Neolithic and early Bronze Age Fngland. Archaeological lournal 129: $22-54$

SALZMAN, L.F. (ed.) 1938. Victoria county history of the county of Cambridgeshise and the Isie of Ely I. London: Oxford University Press.

Silvester. R.J. 1991. The Wissey Embayment and the Fen Causeway, Norfolk, East Anglian Archaeologv 52 .

WALLER, M. 1994. Flandrian environmental change in the Fenland. East Anglian Archaeology 70.

\title{
Some observations on the radiocarbon and cosmogenic isotope dating of petroglyphs, Foz Côa, Portugal
}

\author{
Alan Watchman * \\ Further remarks on the age of the Foz Côa rock-engravings, Portugal, in the light of \\ studies by absolute-science methods in the March 1997 AnTtQuTTY.
}

In the March 1997 issue of ANTIQUTTY, two articles by Fred Phillips et al. (1997: 100-104) and Ron Dorn (1997: 105-15) further contributed on the date of the Côa valley petroglyphs in Portugal. Using in situ chlorine-36, Phillips et al. found evidence that 'indicates how long rock surfaces have been exposed', and 'conclude that panels were available for engraving during the Palaeolithic; they have been exposed 16,000-136,000 years' (Phillips et al. 1997: 100; Chippindale 1997:1). Dorn's (1997) results were less conclusive; he found signs 'that radiocarbon is not safely and stably trapped within rock patinas and varnishes where neither older nor younger carbon can reach it; accordingly radiocarbon determinations on these deposits do not provide true measurements of date' (Chippindale 1997: 1). Unfortunately both papers have critical flaws in their assumptions, and interpretations of analytical results fail to consider the nature of the materials sampled in relation to the event purportedly dated.

Measurements of chlorine-36 in Côa valley schists assume that this isotope only begins to accumulate once a rock panel becomes exposed to the atmosphere and to cosmic rays. This assumption is proved false by the authors' own data where at a depth of $16 \mathrm{~m}$ below the river bed at the proposed dam wall site chlorine-36 was present in quantities equivalent to surface exposure ages of between 795 and 2780 years (Phillips et al. 1997: table 1). The depth of this accumulation is at least eight times greater than that at which in situ cosmogenic isotopes are generally produced because 'one or two metres of rock will block most cosmic radiation' (Phillips et al. 1997: 102). Although muon reactions can produce chlorine-36 beyond these generally accepted shallow depths (Cerling \& Craig 1994: 285), a fundamental problem still exists with the Côa measurements because the authors have shown that buried rock surfaces can also accumulate significant quantities of chlorine-36 before they are exposed to the atmosphere.

Generally, measuring the amount of chlorine36 in a sample taken from an exposed rock surface today indicates the sum of isotopic

\footnotetext{
* School of Anthropology \& Archaeology, James Cook University, Townsville QLD 4811. Australia.
}

Received 3 June 1997, accepted 9 September 1997, revised October 1997.

ANTIQUTTY 72 (1998) 197-200 
contributions from atmospheric, cosmogenic and radioactive sources, assuming that chlorine-36 was not introduced either by prior exposure or from groundwater. Under ideal circumstances of rapid exposure by a cataclysmic event (fault or landslide) of a rock surface to cosmic radiation the in situ cosmogenic chlorine-36 dating process can provide an age estimate for exposure of a surface where atmospheric and nuclear productions are insignificant. However, under slow rates of erosion and/or high levels of introduced atmospheric chlorine-36 a cosmogenic isotope 'age' cannot define when a surface was exposed to the atmosphere. In the Côa valley, where river down-cutting and hill slope erosion are arguably slow and episodic, and where deep rock weathering (iron-stained schists) and ground water movements (fracture fillings) provide evidence of probable atmospheric chlorine-36 contamination the "exposure age' of panels dated by Phillips et al. does not only reflect exposure to the atmosphere. Given that, the calculated in situ cosmogenic ages from exposure of the engraved panels in the Côa valley are too large.

The authors use a range of $0-2 \mathrm{~mm} / \mathrm{millen}$ nium for surface erosion rates because they assume that 'higher rates of surface erosion would have obliterated the engravings' (Phillips et al. 1997: 102). This suggests that the authors either already knew the surfaces had prePalaeolithic ages, or they conveniently ignored the possibility that even at the maximum erosion rate petroglyphs less than 1000 years old would still be visible. Dorn had sampled petroglyphs at locales where the bottoms of the grooves were $\sim 2-4 \mathrm{~mm}$ beneath the adjacent joint face' (Dorn 1997: 106), so erosion rates of up to $4 \mathrm{~mm} /$ millennium would still agree with much younger estimates of petroglyph ages (Bednarik 1995; Watchman 1995b).

Students of chemistry know that all chlorides are soluble, an aspect forgotten by cosmogenic chlorine-36 proponents. Instead of invoking muon production for cosmogenic chlorine at $16 \mathrm{~m}$ depth at the proposed dam site, a simple explanation of groundwater transport of chlorine from higher elevations might be considered. Siliceous minerals are much more soluble in the presence of chloride ions (Wey \& Sieffert 1961) and silica skins have precipitated on some schist surfaces, so groundwater has likely transported atmospherically derived chlorine-36 into the schists. Measurements of chlorine-36 on successive joint faces at Ribeira dos Piscos provide evidence confirming chlorine solubility; analysed rock from the oldest exposed joint surface has the lowest chlorine abundance suggesting that some chlorine has been leached from minerals (Phillips et al. 1997: table 1). Firm conclusions about chlorine-36 mobility in samples analysed by Phillips et al. at Côa cannot be made because the authors did not provide petrographic descriptions to indicate the degree of mineral weathering. They also did not reveal the precise locations from where they collected samples so the analyses may not relate to engraved surfaces.

The focus of the other article is "whether available radiocarbon results constrain the ages of Côa engravings' (Dorn 1997: 105), but his results are from weathering rinds (cortex), and not rock surface coatings or silica glazes as he asserts. He reported only one determination from silica glaze within an overlying rock coating, whereas he made 14 radiocarbon measurements on 'organic matter' from weathering rinds and 5 from the interface between rinds and their overlying coatings (Dorn 1997: table 1, 108). His conclusion that "analytical data indicate that silica glaze at Côa does not form a closed system' (Dorn 1997: 106) therefore has no basis. What he has found instead is that 'organic matter' in weathering rinds does not provide suitable source materials for establishing the age of petroglyphs at Côa because they contain carbon of different ages.

Preliminary dating results for fossilized surfaces and rock paintings have been obtained outside the Côa valley using microexcavation extraction (Arsenault 1996; Watchman 1990; 1992; 1994; 1995a). To confirm that carbonbearing substances were fossilized and trapped in silica accretions in a closed stable system I dated three micro-layers in one skin from Penascosa (one of the Côa petroglyph sites). The micro-layers consisted of a basal layer of silica (FC-7; $3490 \pm 90$ years b.p.), an upper silica layer (FC-6; $2060 \pm 50$ years b.p. and the silty surface (FC-25, modern; Watchman 1995b; table 1). These off-art results establish a chronological sequence consistent with slow accumulation of carbon in a closed, stratified amorphous silica system.

Dorn clearly illustrates the relationship of 'organic matter in pores of weathering rinds' with the overlying silica 'glaze' (Dorn 1997; figure 2), and he infers that it was carbon 'in weathering rinds within petroglyph grooves' 
(p. 106) that he sampled for dating. That example, for which he obtained a radiocarbon age (FC-95-4) shows 'organic matter' at depths exceeding 100 microns beneath the petroglyph surface and almost $0.3 \mathrm{~mm}$ beneath the adjacent joint surface. To sample petroglyph weathering rinds for dating "pieces of schist were chipped from each petroglyph with a tungstencarbide needle' (Dorn 1997: 106), but he gives no information about how the 'organic matter in pores of weathering rind' was extracted and processed for dating. He does not describe the types of 'organic matter' he found. Uncertainty therefore exists as to the inclusion of accidental carbon-bearing contaminants; from graphite in the schist (Watchman 1995b; 1996), from modern carbon during sampling, during processing (Beck et al. 1996), or from conversion to graphite in the dating laboratory. If only 'organic matter' from the weathering rind under petroglyphs was present in samples used for dating, then the measured radiocarbon age reflects the age of the material and not carbon taken from the rock coating or 'inorganic' graphite from the rind. His conclusions therefore relate to material beneath petroglyphs and not to the age of the accretions lying over them. Dorn's determinations for 'organic matter' from weathering rinds are therefore maximum ages. His samples were also probably contaminated by graphite from the schist because he did not separate the different fractions in all samples. Where he did separate weathering rind 'organic matter' into dense and less dense fractions (FC95-5b) he may have only divided it into its two forms; dense graphite stubs and light graphite flakes combined with modern organics. We will never know what was dated because he did not identify the components, only calling them 'organic matter'.

Dorn compares my dating result from a railway quarry of known age (Watchman 1995b: FC-28) with his radiocarbon determination for silica glaze over an unengraved panel surface (FC-95-2a), but he has no idea how old the surface is that he sampled. The only comparison possible is that similar rock surface accretions were sampled from schist in the Côa and that similar radiocarbon results were obtained. I do not share his view about modern carbon exchange in these samples; there is overwhelming evidence to support an opposite hypothesis (Watchman 1996). There is no need to use complex arguments about modern carbon exchange when the simple explanation of accidental inclusion of carbon-14 deficient graphite from the schist underlying rock surface accretions fits all the evidence, including field observations made by all dating parties. The radiocarbon determination of 29,990 years ago, obtained from dense 'organic matter' in the rind of an 'unexposed joint crevice' (Dorn 1997: table 1, FC95-5b), fits this scenario. (It is near the detection limit of AMS radiocarbon for a mixture consisting mostly of graphite.)

The major radiocarbon dating problem at Côa is imprecision in sampling the extremely thin. compositionally variable silica skins. As with all rock surface accretion dating methods, extracting carbon of known identity and origin is very difficult; often the best that can be done. is to take a sequence of stratigraphic samples to verify that a chronological order of deposition exists. Techniques for doing this (Watchman 1993; Watchman \& Campbell 1996) are being refined. Radiocarbon dating results from Côa do date the rock surfaces and the petroglyphs, but not to the estimates and interpretations of Dorn and Phillips et al. Publication of these two papers without details of the methods, the precise locations of samples, the nature of rocks and accretions analysed, the pre-treatment steps, and the weights and identities of carbon-bearing components not only does archaeometry a disservice, but it degrades scientific debate. While the published results are controversial, so are the methods and assumptions, but readers were not provided with enough information to judge the accuracy of the results. Surfaces and materials of known ages were not used to validate these dating approaches adequately in the Côa valley, especially where several potential sources of isotopes were likely.

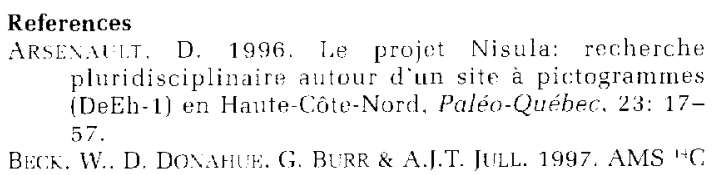
pluridisciplinaire autour d un site à pictogrammes (DeEh-1) en Haute-Côte-Nord, Paléo-Québec. 23: 1757 .

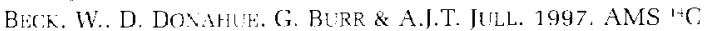

dating of carly Anasazi petroglyphs from North American Southwest desert region. Abstract. 6th Australasian Archacometry conference. Sydney.

BriJnaRIK, R.G. 1995. The age of the Cóa petroglyphs in Portugal. Rock Art Research 12: 86-103. 
CARLNG. T.E. \& H. CRAIG 1994. Geomorphology and in-situ cosmogenic isotopes. Annual Revier Earth Planetary Science $22: 273-317$.

CHIlPIND+1.L. C. 1997. Editorial. Antiquits $71: 1-7$

DoRv. R.I. 1997. Constraining the age of the Cô valley (Portugal) engravings with radiocarbon dating, Antiquity $71: 105-15$

PHILLPS. FM. M. FIIXSCH. D. ElNoRE \& P. SILRML. 1997 Maximum ages of the Cóa valley (Portugal) engravings measured with Chlorine-36. Antiguity 71 : 100-104.

WATCHMAN. A. 1990. What are silica skins and how are they important in rock art conservation? Austwalian Aborigi nal Studies (1990): $21-9$

1992. Composition. formation and age of some Australian silica shins. Australian Aborigmal Studies (1992): 61-6

1993. Evidonce of a 25,000-year old pictograph in Northorn Australia. Geoarchaeology 8(6): 465-73.

1994. Radiocarbon dating of fatty acids in folocene sili- ceous rock surface accretions. Austrolian Jommal of Earth Sciences $41: 179-80$

1995a. Dating Kozar lake pictographs. Abstract. Eastern States Rock Art Conference. Nachias Bay, Maine.

1995b. Recent pelroglsphs. Foz Côa. Portugal. Rock trt Researeh $12,104-6$.

1996. A review of the theors and assumptions in the AMS dating of the Foz Côa petroglyphs. Portugal. Rock Art Resenrch 13: $21-30$.

WATCHMAN. A.\&J. CANBBFI. 1996. Micro-stratigraphic analyses of laminated oxalate crusts in northem Australin. in M. Realini \& L. Toniolo (ed.). The oxalate films in the conservation of rorks of art: 408-22. Bologna: Editeam.

WEY. R. \& B. StFFERT. 1961 . Reaction de la silice monomoléculaire en solution avec les jons Al. Mg: genèse et sunthoso des argiles. Colloguma Internationale Centr: Vational Rocherche Soience (Paris) 105:11-23.

\title{
Celts, politics and motivation in archaeology
}

\section{SIMON JAMES *}

\begin{abstract}
Ruth \& Vincent Megaw questioned the motivation behind the current critique of the use of the term 'Celtic' for the La Tène Iron Age in ANTIQUITY (1996: 175-81). Thev explained it is a nationalist reaction derived from insecurity about modern English identity. Here we have a reply to their paper, which rejects these interpretations.
\end{abstract}

In a recent number of this journal, Ruth \& Vincent Megaw painted an extraordinary picture of the activities of 'some English archaeologists' who study the Iron Age (NB not British; the movement in question is presented as something no Scottish or Welsh archaeologist would subscribe to; Megaw \& Megaw 1996: e.g. figure 2).

They see a new school of thought emerging. attacking the long-established academic and popular consensus that the Iron Age of huge tracts of Europe is best understood in terms of a fairly uniform Celtic culture which, while exhibiting local variations, was fundamentally similar in language, social structures and material culture. These 'English archaeologists', they believe, would deny not only the Celticity of ancient Europe, but in consequence also the authenticity of the modern Celtic world.

Seeking to explain the underlying motivation for this perceived development in the context of the United Kingdom of the 1980s, they suggest that the individuals concerned are motivated by dangerous nationalist forces. The Megaws contrast their own highly multicultural academic milieu in Australia with, at least by implication, a more monocultural, and specifically English-dominated, environment in the United Kingdom (Megaw \& Megaw 1996: 175). They suggest. again partly by implication. that hostility to the idea of a common Celtic identity for the people of Iron Age Britain is motivated, subliminally if not consciously, by the same beliefs and fears as those behind current right-wing English nationalist politics. The Megaws build a picture of specifically English academic cultural imperialism attempting to undermine the unity of Celtic peoples, ancient and modern, as a parallel to, if not an integral part of, the Little Englandism and Europhobia of the Tory Right in wider British political life (Megaw \& Megaw 1996: 180):

In the United Kingdom . . particularly in England, the anti-European mentality seems deeply entrenched; promoting a fear of 'loss of sovereignty' seems to the Tory Right its main hope of maintaining political control. Celts, ancient or modern, are seen as a possible svmbol of internal disintegration and external control: hence, perhaps. the question-

* Department of Archneology: University of Durham. South Road, Durhan DH1 3*.E. England. s.t.jamos@durham.ac.uk

Received 16 June 1997 , accepted 20 October 1997, revised 9 December 1997.

A $\triangle$ TIQLTTY 72 (1998): 200-209 